\title{
Assessment of regional lung ventilation by electrical impedance tomography in a patient with unilateral bronchial stenosis and a history of tuberculosis*
}

Avaliação da ventilação pulmonar regional por tomografia de impedância elétrica em paciente com estenose brônquica unilateral pós-tuberculose

Liégina Silveira Marinho, Nathalia Parente de Sousa,

Carlos Augusto Barbosa da Silveira Barros, Marcelo Silveira Matias, Luana Torres Monteiro, Marcelo do Amaral Beraldo, Eduardo Leite Vieira Costa, Marcelo Britto Passos Amato, Marcelo Alcantara Holanda

\begin{abstract}
Bronchial stenosis can impair regional lung ventilation by causing abnormal, asymmetric airflow limitation. Electrical impedance tomography (EIT) is an imaging technique that allows the assessment of regional lung ventilation and therefore complements the functional assessment of the lungs. We report the case of a patient with left unilateral bronchial stenosis and a history of tuberculosis, in whom regional lung ventilation was assessed by EIT. The EIT results were compared with those obtained by ventilation/perfusion radionuclide imaging. The patient was using nasal continuous positive airway pressure (CPAP) for the treatment of obstructive sleep apnea syndrome. Therefore, we studied the effects of postural changes and of the use of nasal CPAP. The EIT revealed heterogeneous distribution of regional lung ventilation, the ventilation being higher in the right lung, and this distribution was influenced by postural changes and CPAP use. The EIT assessment of regional lung ventilation produced results similar to those obtained with the radionuclide imaging technique and had the advantage of providing a dynamic evaluation without radiation exposure.
\end{abstract}

Keywords: Tomography; Electric impedance; Positive-pressure respiration; Pulmonary ventilation; Airway obstruction; Tuberculosis, pulmonary.

\section{Resumo}

A estenose brônquica pode comprometer a ventilação pulmonar regional devido a limitações anormais e assimétricas ao fluxo aéreo. A tomografia de impedância elétrica (TIE) é uma técnica que possibilita a avaliação da ventilação pulmonar regional por imagem e, portanto, pode complementar a avaliação funcional dos pulmões. Relatamos o caso de uma paciente com estenose brônquica unilateral à esquerda, pós-tuberculose, em que se avaliou a ventilação pulmonar regional através da TIE, relacionando-a com a cintilografia de ventilação/perfusão. Foram estudados os efeitos das mudanças posturais e da aplicação de continuous positive airway pressure (CPAP, pressão positiva contínua nas vias aéreas) nasal, uma vez que a paciente usava esse tratamento para síndrome da apneia obstrutiva do sono. A TIE demonstrou distribuição heterogênea da ventilação pulmonar regional com maior ventilação no pulmão direito, sendo essa distribuição influenciada pelas mudanças de decúbitos e pela aplicação de CPAP. A análise da ventilação pulmonar regional pela TIE se mostrou similar aos achados da cintilografia pulmonar de ventilação com a vantagem de possibilitar uma avaliação dinâmica e sem exposição à radiação.

Descritores: Tomografia; Impedância elétrica; Respiração com pressão positiva; Ventilação pulmonar; Obstrução das vias respiratórias; Tuberculose pulmonar.

\footnotetext{
* Study carried out at the Federal University of Ceará, Fortaleza, Brazil.

Correspondence to: Liégina Silveira Marinho. Avenida Gonçalves Dias, 509, Rodolfo Teófilo, CEP 60431-145, Fortaleza, CE, Brasil. Tel. 5585 3366-8499. E-mail: lieginasm@gmail.com

Financial support: This study received financial support from the Coordenação de Aperfeiçoamento de Pessoal de Nível Superior (CAPES, Office for the Advancement of Higher Education). Carlos Augusto Barbosa da Silveira Barros and Marcelo Silveira Matias are recipients of scholarships from the Programa Institucional de Bolsas de Iniciação Científica (PIBIC, Institutional Program for Scientific Initiation Scholarships), which is affiliated with the Respiration Laboratory of the Federal University of Ceará.

Submitted: 19 October 2012. Accepted, after review: 25 January 2013.
} 


\section{Introduction}

Tuberculosis remains a serious public health problem worldwide and can lead to various sequelae in the respiratory tract, one of which is bronchial stenosis. ${ }^{(1-5)}$ Bronchial stenosis can lead to dyspnea due to airflow obstruction, with the aggravating factor that it is often characterized by asymmetric, proximal airway lesions. The left main bronchus is particularly susceptible to this complication. ${ }^{(6,7)}$

Pulmonary function tests evaluate lung function as a whole, but tell nothing about regional changes in ventilation. These changes are usually evaluated using radioisotope scintigraphy, which is costly and not widely available in Brazil.

Electrical impedance tomography (EIT) is a technique that allows safe, real-time, dynamic image reconstruction of axial slices of the lung, making it possible to assess regional lung ventilation. ${ }^{(8)}$ This tool is particularly promising in cases of asymmetric lung disease, such as unilateral bronchial stenosis.

We report the case of a female patient with stenosis of the left main bronchus and obstructive sleep apnea syndrome (OSAS), who was being treated with nasal continuous positive airway pressure (CPAP) and in whom regional lung ventilation was assessed by EIT. We highlight the effects of postural changes and of the use of CPAP on regional lung ventilation.

\section{Case report}

A 53-year-old female nonsmoker who had been treated for tuberculosis at the age of 20 presented with a three-year history of progressive dyspnea. Pulmonary auscultation revealed rhonchi and wheezing in the left hemithorax.

Spirometry showed the following: FVC, $2.56 \mathrm{~L}$ (88\%); FEV 1 , 1.81 L (77\%); FEV $/$ /FVC, 0.71 (88\%); and $\mathrm{FEF}_{25-75 \%}, 1.15 \mathrm{~L} / \mathrm{s}(50 \%)$. These results are consistent with mild obstructive lung disease. No significant bronchodilator response was observed.

Digital reconstruction of CT scans of the chest showed narrowing of the left main bronchus, beginning at its origin and reaching $4.8 \mathrm{~cm}$ along its length, with a width of $0.5 \mathrm{~cm}$ (Figure $1 \mathrm{~A}-\mathrm{D})$. Forced exhalation increased the degree of bronchial stenosis, resulting in almost complete collapse and causing air trapping in the left lung. Ventilation/perfusion radionuclide imaging (Figure $1 \mathrm{E}$ and $1 \mathrm{~F}$ ) showed that the blood flow and ventilation were directed to the right lung (68\%). Bronchoscopy confirmed the chest CT finding of left bronchial stenosis.

We used an ElT device with 32 electrodes (DX 1800, Dixtal Biomédica, Manaus, Brazil) ${ }^{(6,7)}$ to assess regional lung ventilation, as well as the effects of different postures-supine position (SP), right lateral decubitus position (RLDP), and left lateral decubitus position (LLDP)-and of CPAP use $\left(10 \mathrm{cmH}_{2} \mathrm{O}\right)$. In all situations, the patient lay for $10 \mathrm{~min}$ with the head elevated $30^{\circ}$, and the measurements under the different conditions were taken 5 min apart.

Figure 2 shows functional maps of the distribution of regional lung ventilation in the three postures during spontaneous breathing and during the use of nasal CPAP, all of which were constructed on the basis of ElT.

Video 1 (available online at http://www. jornaldepneumologia.com.br/detalhe_artigo_ pre_visualizar.asp?id=2236) features a dynamic demonstration of regional lung ventilation in the three postures during spontaneous breathing and during CPAP use. During spontaneous breathing, it is possible to see that the ventilation was almost entirely directed to the right side, being represented by a light-blue color; a lighter shade of blue translates to higher ventilation in that area. During CPAP use, a portion of the ventilation was distributed to the left lung.

\section{Discussion}

In the present case, the relative distribution of regional lung ventilation, during spontaneous breathing, was always higher in the right lung, with values of $91 \%, 82 \%$, and $58 \%$ for the SP, the RLDP, and the LLDP, respectively, which shows the effect of bronchial stenosis on the distribution of regional lung ventilation and the influence of postural changes (Figure 2). The images obtained by EIT are consistent with those obtained with the radionuclide imaging technique.

In healthy individuals breathing spontaneously and placed in the SP, regional lung ventilation is higher in the dependent regions than in the nondependent regions, a physiological phenomenon that has been well documented by studies using EIT. Studies using EIT in healthy volunteers have shown the marked influence of postural changes on the distribution of lung ventilation. Studies analyzing regional lung ventilation in healthy 

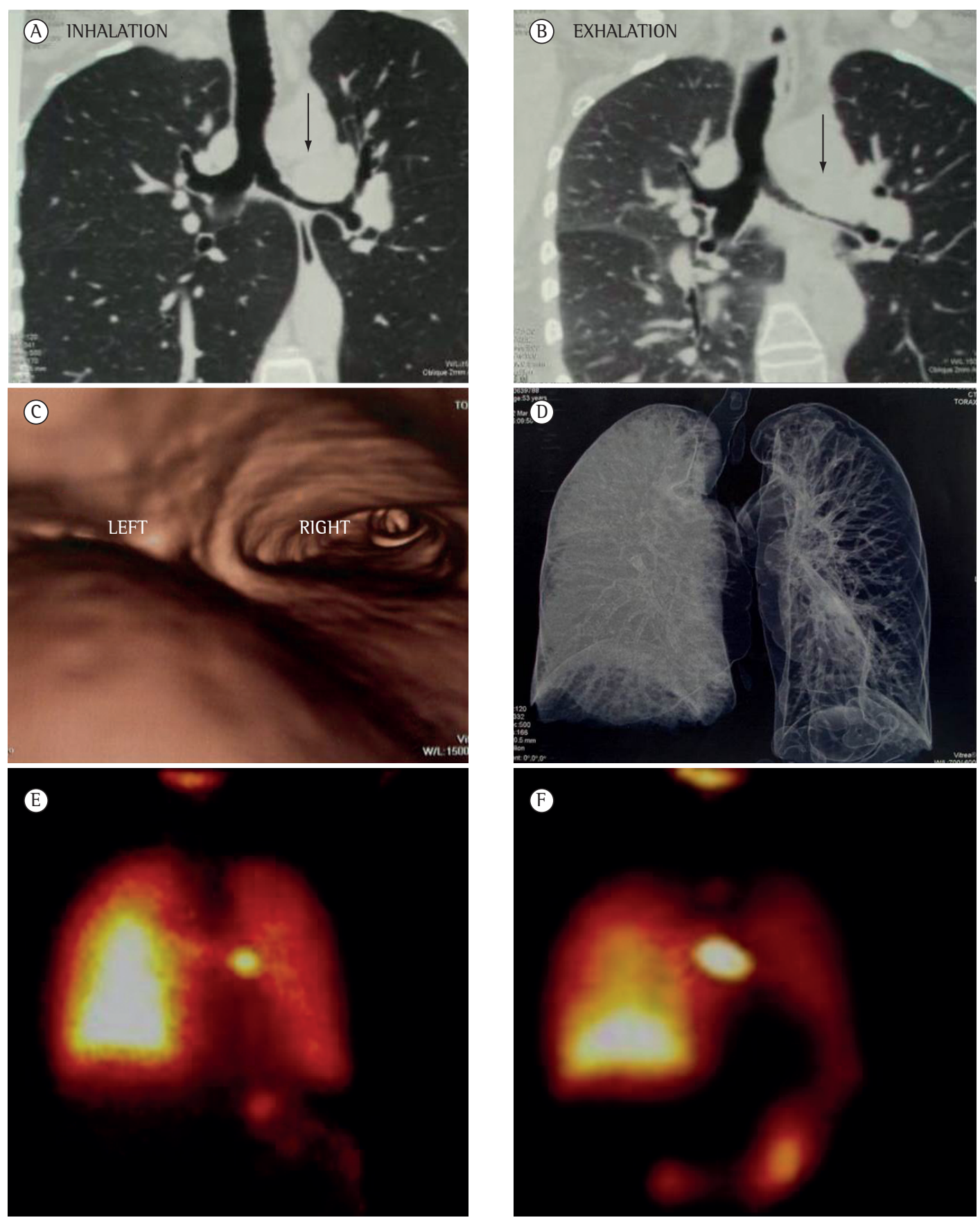

Figure 1 - Coronal reconstruction of multidetector chest CT scans acquired during inhalation (A) and exhalation (B), endobronchial reconstruction of a multidetector chest CT scan (C), and volumetric reconstruction of a multidetector chest CT scan acquired at end-exhalation showing air trapping in the left lung (D); as well as radionuclide lung perfusion (E) and lung ventilation (F) images. The arrows show the site of the bronchial stenosis.

volunteers have shown it to be invariably higher toward the dependent lung in the lateral decubitus positions. ${ }^{(9,10)}$

During CPAP use $\left(10 \mathrm{cmH}_{2} 0\right)$, the differences in the regional distribution of ventilation increased. In the postures studied, the gravitational distribution of ventilation occurred mostly toward the dependent regions. In the SP, the use of CPAP caused a slight redistribution of regional ventilation to the left lung, predominantly to its dorsal portion. In contrast, the RLDP resulted in an increase in ventilation asymmetry, concentrating 
SP
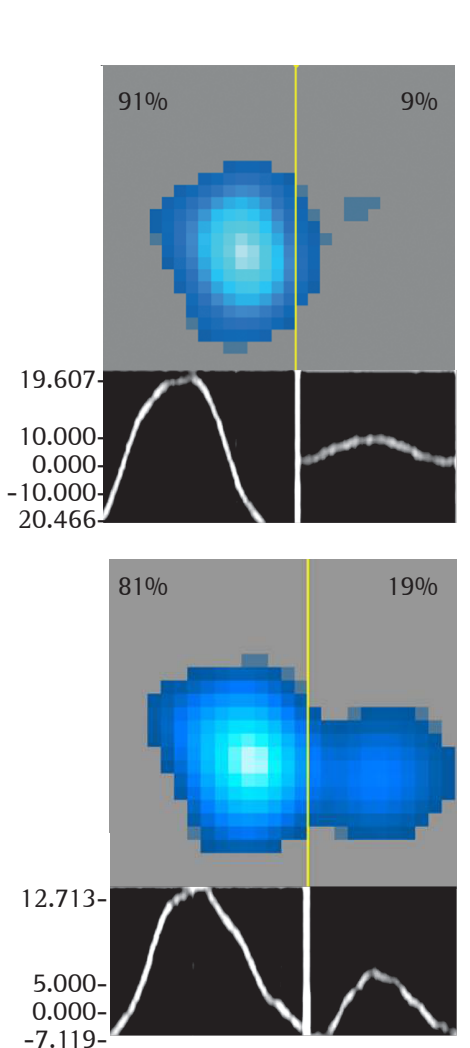

RLDP

SPONTANEOUS BREATHING
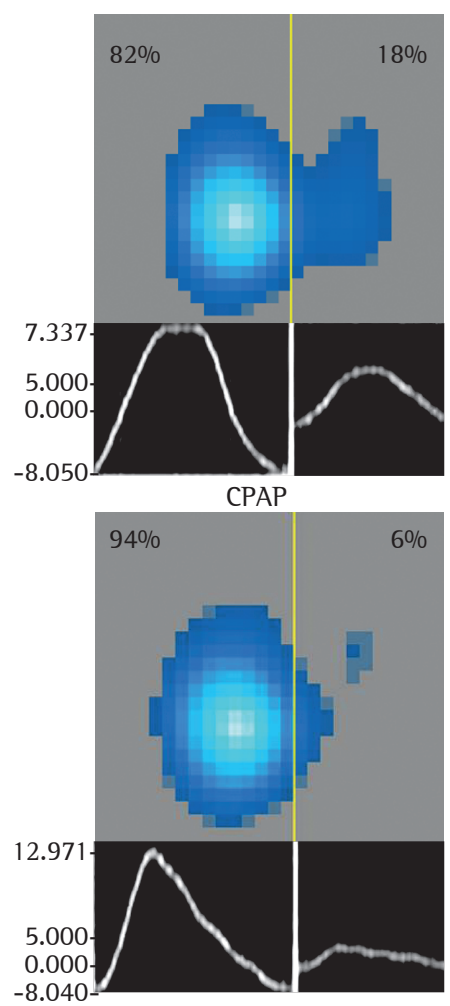

LLDP
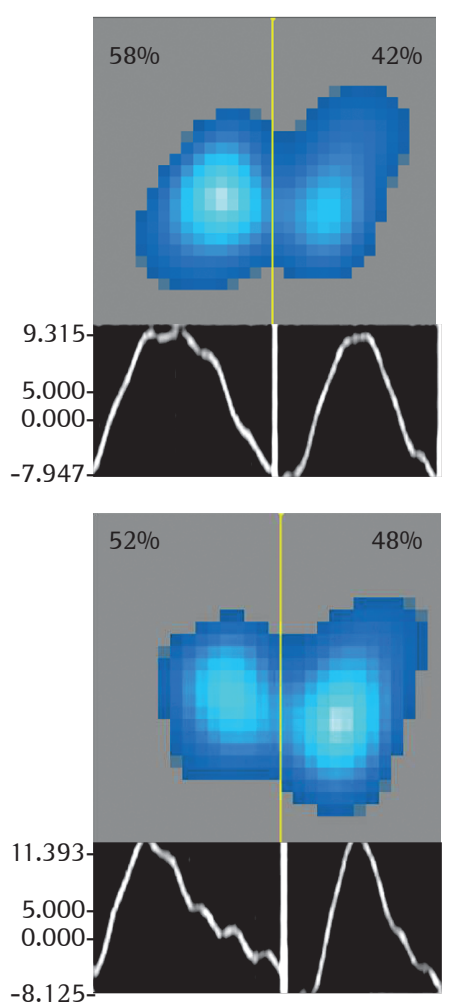

Figure 2 - Functional map of the distribution of regional lung ventilation as assessed by electrical impedance tomography in the supine position (SP), in the right lateral decubitus position (RLDP), and in the left lateral decubitus position (LLDP). The three first images were obtained during spontaneous breathing. The three last images were obtained during the use of continuous positive airway pressure (CPAP; $10 \mathrm{cmH}_{2} 0$ ). The percentages represent the distribution of tidal volume to each lung. At the bottom of each figure, there is the plethysmographic curve showing the variation in electrical impedance.

ventilation almost entirely in the right lung. In the LLDP, ventilation to the dependent lung increased from $42 \%$ to $48 \%$, possibly because of mechanical bronchodilation of the left bronchus caused by CPAP use. ${ }^{(8)}$

The present case strengthens the interest in using EIT to assess regional lung ventilation, especially in cases of asymmetric airway lesions. In addition, when compared with radionuclide imaging, ElT has the advantage of being a hightemporal resolution method that dynamically evaluates the effects of postural changes and of CPAP use.

\section{References}

1. Bombarda S, Figueiredo CM, Funari MB, Soares Jr J, Seiscento M, Filho MT. Imagem em tuberculose pulmonar. J Pneumol. 2001;27(6):329-40. http://dx.doi.org/10.1590/ S0102-35862001000600007
2. Barreira D, Grangeiro A. Evaluation of tuberculosis control strategies in Brazil. Foreword [Article in Portuguese]. Rev Saude Publica. 2007;41 Suppl 1:4-8. http://dx.doi. org/10.1590/S0034-89102007000800002 PMid:18038085

3. McConkey M, Greenberg S. Persistent rhonchi in the diagnosis of bronchial stenosis complicating pulmonary tuberculosis. Trans Am Clin Climatol Assoc. 1934;50:21823. PMid:21407480 PMCid:PMC2441225

4. Anjos DM, Junqueira JJ, Gomes DB, Terra RM, Minamoto H, Jatene FB. Endopróteses: opção terapêutica para estenoses traqueobrônquicas adquiridas. Rev Med (Sao Paulo). 2007;86(3):174-84.

5. Lyons HA. The diagnosis of bronchial stenosis. Dis Chest. 1950;18(1):16-26. http://dx.doi.org/10.1378/ chest.18.1.16 PMid:15421236

6. Costa EL, Lima RG, Amato MB. Electrical impedance tomography. Curr Opin Crit Care. 2009;15(1):18-24. http://dx.doi.org/10.1097/MCC.0b013e3283220e8c PMid:19186406

7. Victorino JA, Borges JB, Okamoto VN, Matos GF, Tucci MR, Caramez MP, et al. Imbalances in regional lung ventilation: a validation study on electrical impedance tomography. Am J Respir Crit Care Med. 2004;169(7):791- 
800. http://dx.doi.org/10.1164/rccm.200301-1330C PMid:14693669

8. Frerichs 1, Dudykevych T, Hinz J, Bodenstein M, Hahn G, Hellige G. Gravity effects on regional lung ventilation determined by functional ElT during parabolic flights. J Appl Physiol (1985). 2001;91(1):39-50.

9. Reifferscheid F, Elke G, Pulletz S, Gawelczyk B, Lautenschläger 1, Steinfath M, et al. Regional ventilation distribution determined by electrical impedance tomography: reproducibility and effects of posture and chest plane. Respirology. 2011;16(3):523-31. http://dx.doi.org/10.1111/j.1440-1843.2011.01929.x PMid:21261780

10. Matias MS, Barros CA, Monteiro LT, Sousa NP, Marinho LS, Reis RC, et al. Impacto da ventilação não invasiva (VNI) nos modos CPAP e Bilevel sobre a distribuição da ventilação pulmonar avaliada através do tomógrafo de impedância elétrica (TIE). Rev Bras Ter Intensiva. 2011;Suppl 1:S3.

\section{About the authors}

\section{Liégina Silveira Marinho}

Master's Student. Graduate Program in Medical Sciences, Federal University of Ceará; and Researcher, Respiration Laboratory, Center for Biomedicine, Federal University of Ceará, Fortaleza, Brazil.

\section{Nathalia Parente de Sousa}

Master's Student. Graduate Program in Medical Sciences, Federal University of Ceará; and Researcher, Respiration Laboratory, Center for Biomedicine, Federal University of Ceará, Fortaleza, Brazil.

\section{Carlos Augusto Barbosa da Silveira Barros}

Medical Student. Federal University of Ceará, Fortaleza, Brazil.

\section{Marcelo Silveira Matias}

Medical Student. Federal University of Ceará, Fortaleza, Brazil.

\section{Luana Torres Monteiro}

Doctoral Student. Graduate Program in Biotechnology, Federal University of Ceará, Fortaleza, Brazil.

\section{Marcelo do Amaral Beraldo}

Researcher. University of São Paulo, São Paulo, Brazil.

\section{Eduardo Leite Vieira Costa}

Intensivist. Hospital Sírio-Libanês; and Researcher. University of São Paulo, São Paulo, Brazil.

\section{Marcelo Britto Passos Amato}

Respiratory ICU Supervisor. University of São Paulo School of Medicine Hospital das Clínicas, São Paulo, Brazil.

\section{Marcelo Alcantara Holanda}

Associate Professor. Department of Clinical Medicine, Federal University of Ceará, Fortaleza, Brazil. 